\title{
Surgical Management of Midline Anterior Skull Base Meningiomas: Experience of 30 Cases
}

\section{Orta Hat Anterior Kafa Kaidesi Menenjiyomlarnm Cerrabi Tedavisi: 30 Olguluk Deneyim}

\author{
Mohamed I REFAAT, Ehab M EISSA, Mohamed H ALI \\ Cairo University Hospitals, Department of Neurosurgery, El Manial, Cairo, Egypt
}

Corresponding Author: Mohamed I REFAAT / E-mail: mrefaat_77@yahoo.co.uk

\begin{abstract}
AIM: Midline anterior skull base meningiomas include olfactory groove meningiomas (OGMs), Tuberculum Sellae meningiomas (TSMs), and planum sphenoidale meningiomas (PSMs). The main surgical challenge in treating these lesions is to excise the tumor totally without causing mortality or morbidity. Studying the clinical patterns and the surgical outcomes of these lesions.

MATERIAL and METHODS: Thirty cases of midline anterior skull base lesions were included in our study. Patients were operated upon by four routes: (i) unilateral subfrontal, (ii) bilateral subfrontal, (iii) frontotemporal approach, and (iv) bifrontal basal interhemispheric. Extent of resection was classified according to the Simpson grading system. The functional outcome of the patients was assessed by comparing the preoperative and the postoperative neurological examination, as well as the Karnofsky performance scale.

RESULTS: We had 14 OGMs (46.7\%), 9 TSMs (30\%), and 7 PSMs (23.3\%). The most commonly utilized approach was the subfrontal approach (unilateral or bilateral) in $80 \%$ of the cases, followed by the pterional approach in $16.6 \%$ of the cases. Total removal was achieved in $86.7 \%$ of the cases; subtotal excision was achieved in $13.3 \%$ of the cases. $41.2 \%$ of our cases showed postoperative clinical improvement. We had two mortalities in our study, representing $6.7 \%$. We did not detect any tumor recurrences in our follow up. The median preoperative Karnofsky scale was 85 , while the median postoperative Karnofsky scale was 90.
\end{abstract}

CONCLUSION: Midline anterior skull base lesions are becoming amenable for total surgical excision with minimal morbidities and mortalities. Most preferred surgical routes are the subfrontal and the pterional approaches.

KEYWORDS: Olfactory groove meningiomas, Planum sphenoidale meningiomas, Tuberculum sellae meningiomas, Simpson grade

öz

AMAÇ: Orta hat anterior kafa kaidesinin menenjiyomları olfaktör oluk menenjiyomları (OOM'ler), tüberkulum sella menenjiyomları (TSM'ler) ve planum sfenoidale menenjiyomları (PSM'leri) içerir. Bu lezyonların tedavisindeki ana cerrahi zorluk tümörün herhangi bir mortalite veya morbiditeye neden olmadan tümüyle eksizyonudur. Bu lezyonların klinik paternleri ve cerrahi sonuçları çalışılmıştır.

YÖNTEM ve GEREÇLER: Çalışmaya otuz orta hat anterior kafa kaidesi lezyonu dahil edilmiştir. Hastalar dört yolla ameliyat edilmiştir: (i) ünilateral subfrontal, (ii) bilateral subfrontal, (iii) frontotemporal yaklaşım ve (iv) bifrontal bazal interhemisferik. Rezeksiyon kapsamı Simpson derecelendirme sistemine göre sınıflandırılmıştır. Hastaların işlevsel sonucu preoperatif ve postoperatif nörolojik muayenenin ve Karnofsky performans ölçeği sonuçlarının karşılaştırılmasıyla değerlendirilmiştir.

BULGULAR: 14 OOM (\%46,7), 9 TSM (\%30) ve 7 PSM $(\% 23,3)$ mevcuttur. En sık kullanılan yaklaşım, olguların \%80'inde kullanılan subfrontal yaklaşım (unilateral veya bilateral) olmuş ve bunu olguların \%16,6'sında pterional yaklaşım takip etmiş̧tir. Total eksizyon olguların \% 86,7 'sinde ve subtotal eksizyon \%13,3'ünde elde edilmiştir. Olguların \%41,2'sinde postoperatif klinik düzelme görülmüştür. Çalışmada \%6,7'yi temsil edecek şekilde iki mortalite görülmüştür. Takipte herhangi bir tümör nüksü saptanmamıştır. Medyan preoperatif Karnofsky ölçeği değeri 85 ve medyan postoperatif Karnofsky ölçeği değeri 90 olmuştur.

SONUÇ: Orta hat anterior kafa kaidesi lezyonları minimum morbidite ve mortalite ile total cerrahi eksizyona uygun hale gelmektedir. En çok tercih edilen cerrahi yollar subfrontal ve pterional yaklaşımlardır.

ANAHTAR SÖZCÜKLER: Olfaktör oluk menenjiyomları, Planum sfenoidale menenjiyomları, Tüberkulum sella menenjiyomları, Simpson sınıfı

ABBREVIATIONS: OGMS: olfactory groove meningiomas, PSMs: planum sphenoidale meningiomas, TSMs: tuberculum sellae meningiomas 


\section{INTRODUCTION}

Meningiomas are slowly growing benign tumors arising from arachnoid cap cells. They constitute about $20 \%$ of all primary intracranial tumors. Olfactory groove meningiomas represent $10 \%$ of this percentage (16). The midline meningiomas of anterior skull base are classified by the site of their dural attachment into: Olfactory Groove Meningiomas (OGM), Planum Sphenoidale Meningioma and Tuberculum Sellae Meningiomas (TSM) (4). Of those, OGMs and TSMs are the most common (9). OGMs arise over the cribriform plate and frontosphenoid suture, predominantly in the midline, but they may extend more to one side. They can reach the ethmoid sinuses, the nasal cavity, or the orbit (5). Common clinical presentations of OGMs are: personality changes, headache, visual manifestations, incontinence and FosterKennedy syndrome (1). TSMs originate from the region of the tuberculum sellae, chiasmatic sulcus, limbus sphenoidale and grow in a subchiasmal location. Visual impairment is the most common complaint followed by headache, mental changes, anosmia and hypothalamic hypophyseal dysfunction (6).

The main surgical challenge in skull base meningiomas is to remove the tumor without morbidity or mortality. Some authors advocate a radical approach with total tumor removal while others favor a more conservative attitude, supported by the natural history of these tumors being slowly growing (16). The common surgical approaches to midline anterior skull base lesions are: the standard pterional, the subfrontal, and the anterior interhemispheric approaches. When considering any approach, the following goals should be targeted: early interruption of the tumor blood supply, careful separation of the frontal lobes from the tumor; dissection of the important structures mainly the anterior cerebral arteries, optic nerves, and chiasm; and adequate visualization of the anterior cranial fossa floor to allow total tumor excision and repair of skull base defects $(2,5)$.

\section{MATERIAL and METHODS}

This study was conducted prospectively on 30 patients presenting with midline anterior skull base meningiomas who presented to the Neurosurgery department of Cairo University Hospitals between March 2012 and August 2013. We studied patients with Olfactory Groove (OGM), Planum Sphenoidale (PSM), and Tuberculum Sellae Meningiomas (TSM). Patients with other non-midline anterior skull base meningiomas, as well as recurrent cases, were excluded from this study.

A full history was taken from all cases. Full preoperative and postoperative neurological examination was also done for all cases. Routine preoperative laboratory investigations were conducted for all patients. All patients were assessed by $\mathrm{CT}$ and MRI brain with contrast preoperatively, follow up CT scans were conducted 24 hours postoperatively, and MRI within 3 days. Late follow up MRI was done within a period of 6 to 12 months postoperatively to detect early recurrences.
Operative management: after routine preoperative preparation, the 30 patients included in this study were operated upon via one of these four different surgical approaches; (i) unilateral subfrontal, (ii) bilateral subfrontal, (iii) frontotemporal approach, and (iv) bifrontal basal interhemispheric. The extent of resection was assessed microscopically during surgery and postoperatively using $\mathrm{CT}$ or MRI imaging. The extent of resection was classified according to the Simpson grading system (13). The functional outcome of the patients was assessed by comparing the preoperative and the postoperative neurological examination, as well as the Karnofsky performance scale (KPS) (7). Patients were classified into three groups according to the KPS; (i) Normal function or minimal symptoms - KPS score 80-100, (ii) Independent but not able to work - KPS score 50-70, (iii) Moderate or severe disability - KPS score $<50$.

\section{RESULTS}

The data collected from 30 cases of surgically managed midline anterior skull base meningiomas was analyzed (Table I).

Incidence: During the 18 months of our study, 250 cases with cranial meningiomas presented to our department. During this period we had 30 cases of midline anterior skull base meningiomas, with a percentage of $12 \%$.

Age \& Sex: Age of patients in our study ranged from 35 years and 67 years, the mean age was 51.5 and standard deviation (SD) was 1.7. There was a great female predominance. There were 24 females $(80 \%)$ and 6 males (20\%) with a female/male ratio of $(4 / 1)$.

Clinical presentation: The most common clinical presentation in our study was headache in 21 cases $(70 \%)$, followed by diminution of vision in 19 cases (63\%), anosmia occurred in 6 cases (20\%), behavioral changes in 4 cases (13\%), and seizures in 4 cases (13\%). Fundoscopic examination revealed the presence of unilateral optic atrophy in 3 cases $(10 \%)$, bilateral optic atrophy in 3 cases (10\%). Papilledema was detected bilaterally in 12 cases (40\%) with large meningiomas and massive edema, while unilateral papilledema with optic atrophy in the other side (Foster-Kennedy syndrome) appeared in 2 cases (6.7\%).

Location of neoplasms: We had 14 OGMs (46.6\%), 9 TSMs (30\%), and 7 PSMs (23.3\%).

Radiologic appearance: OGMs were the largest in size at initial presentation followed by PSMs and then TSMs (Table II). The most common radiologic finding was perifocal edema, seen in 16 cases (53\%), followed by hyperostosis in 9 cases, calcification in 7 cases, vascular encasement in 6 cases, paranasal sinus invasion in 2 cases and cavernous sinus invasion in 2 cases.

The surgical approach was chosen according to the tumor type, size, and extension. The most common utilized approach was the subfrontal approach (unilateral or bilateral) in $80 \%$ of cases (Table III). 
Table I: Summary of Patient's Data

\begin{tabular}{|c|c|c|c|c|c|c|c|c|c|}
\hline $\begin{array}{l}\text { Case } \\
\text { no }\end{array}$ & $\begin{array}{l}\text { Age } \\
\text { Yrs. }\end{array}$ & Sex & $\begin{array}{c}\text { Clinical } \\
\text { presentation }\end{array}$ & Location & $\begin{array}{c}\text { Size } \\
\text { (max } \\
\text { diameter) } \\
\text { cm }\end{array}$ & $\begin{array}{l}\text { Surgical } \\
\text { approach }\end{array}$ & $\begin{array}{l}\text { Degree } \\
\text { of } \\
\text { excision }\end{array}$ & $\begin{array}{l}\text { Morbidities } \\
\text { and } \\
\text { mortalities }\end{array}$ & $\begin{array}{l}\text { Improvement } \\
\text { in vision }\end{array}$ \\
\hline 1 & 50 & $\mathrm{~F}$ & $\begin{array}{l}\text { Anosmia } \\
\text { Headache }\end{array}$ & OGM & 5.8 & $\begin{array}{l}\text { Unilateral } \\
\text { subfrontal }\end{array}$ & Total & $\begin{array}{l}\text { Brain edema } \\
\text { Seizures }\end{array}$ & \\
\hline 2 & 54 & $\mathrm{~F}$ & $\begin{array}{c}\text { Anosmia } \\
\text { Visual } \\
\text { manifestations }\end{array}$ & OGM & 5.4 & $\begin{array}{l}\text { Unilateral } \\
\text { subfrontal }\end{array}$ & Total & Hydrocephalus & Improved \\
\hline 3 & 59 & $\mathrm{~F}$ & $\begin{array}{c}\text { Behavioral } \\
\text { changes } \\
\text { Visual } \\
\text { manifestations }\end{array}$ & OGM & 5.9 & $\begin{array}{l}\text { Bilateral } \\
\text { subfrontal }\end{array}$ & Total & CSF leak & Improved \\
\hline 4 & 44 & $\mathrm{~F}$ & $\begin{array}{c}\text { Anosmia } \\
\text { Visual } \\
\text { manifestations }\end{array}$ & OGM & 7.7 & $\begin{array}{l}\text { Bilateral } \\
\text { subfrontal }\end{array}$ & Total & CSF leak & Stationary \\
\hline 5 & 35 & $\mathrm{~F}$ & $\begin{array}{l}\text { Behavioral } \\
\text { changes } \\
\text { Headache }\end{array}$ & OGM & 4 & Frontotemporal & Total & Brain edema & \\
\hline 6 & 48 & $\mathrm{~F}$ & $\begin{array}{l}\text { Headache } \\
\text { Seizure }\end{array}$ & OGM & 4.7 & Frontotemporal & Subtotal & Brain edema & \\
\hline 7 & 55 & $\mathrm{~F}$ & $\begin{array}{l}\text { Anosmia } \\
\text { Headache }\end{array}$ & OGM & 5.6 & $\begin{array}{l}\text { Bilateral } \\
\text { subfrontal }\end{array}$ & Total & CSF leak & \\
\hline 8 & 47 & $F$ & $\begin{array}{c}\text { Visual } \\
\text { manifestations } \\
\text { Headache }\end{array}$ & OGM & 4.4 & $\begin{array}{l}\text { Unilateral } \\
\text { subfrontal }\end{array}$ & Total & $\begin{array}{l}\text { Wound } \\
\text { infection }\end{array}$ & Stationary \\
\hline 9 & 60 & $\mathrm{~F}$ & $\begin{array}{c}\text { Anosmia } \\
\text { Headache }\end{array}$ & OGM & 5.9 & $\begin{array}{l}\text { Bilateral } \\
\text { subfrontal }\end{array}$ & Total & CSF leak & \\
\hline 10 & 58 & $\mathrm{~F}$ & $\begin{array}{c}\text { Headache } \\
\text { Visual } \\
\text { manifestations }\end{array}$ & OGM & 6.4 & $\begin{array}{l}\text { Bilateral } \\
\text { subfrontal }\end{array}$ & Subtotal & Mortality & $\begin{array}{l}\text { Couldn't be } \\
\text { assessed }\end{array}$ \\
\hline 11 & 67 & $\mathrm{~F}$ & Headache & OGM & 5.5 & $\begin{array}{l}\text { Bilateral } \\
\text { subfrontal }\end{array}$ & Total & Brain edema & \\
\hline 12 & 45 & $F$ & $\begin{array}{c}\text { Visual } \\
\text { manifestations }\end{array}$ & TSM & 2.1 & $\begin{array}{l}\text { Unilateral } \\
\text { subfrontal }\end{array}$ & Total & & Improved \\
\hline 13 & 47 & $\mathrm{~F}$ & $\begin{array}{c}\text { Visual } \\
\text { manifestations } \\
\text { Headache }\end{array}$ & TSM & 2.4 & $\begin{array}{l}\text { Unilateral } \\
\text { subfrontal }\end{array}$ & Total & & Improved \\
\hline 14 & 54 & $\mathrm{~F}$ & $\begin{array}{c}\text { Visual } \\
\text { manifestations } \\
\text { Headache }\end{array}$ & TSM & 2.2 & $\begin{array}{l}\text { Unilateral } \\
\text { subfrontal }\end{array}$ & Total & & Improved \\
\hline 15 & 42 & $\mathrm{~F}$ & $\begin{array}{c}\text { Visual } \\
\text { manifestations } \\
\text { Headache }\end{array}$ & TSM & 1.5 & $\begin{array}{l}\text { Unilateral } \\
\text { subfrontal }\end{array}$ & Total & & Improved \\
\hline 16 & 60 & $F$ & $\begin{array}{c}\text { Visual } \\
\text { manifestations } \\
\text { Headache }\end{array}$ & TSM & 3.6 & Frontotemporal & Total & & Improved \\
\hline 17 & 44 & $\mathrm{~F}$ & $\begin{array}{l}\text { Headache } \\
\text { Seizure }\end{array}$ & TSM & 2.3 & Frontotemporal & Total & $\begin{array}{l}\text { Diabetes } \\
\text { insipidus }\end{array}$ & \\
\hline 18 & 48 & $\mathrm{~F}$ & $\begin{array}{c}\text { Visual } \\
\text { manifestations }\end{array}$ & TSM & 1.9 & $\begin{array}{l}\text { Unilateral } \\
\text { subfrontal }\end{array}$ & Total & Seizure & Stationary \\
\hline
\end{tabular}


Table I: Cont.

\begin{tabular}{|c|c|c|c|c|c|c|c|c|c|}
\hline 19 & 54 & $F$ & $\begin{array}{c}\text { Visual } \\
\text { manifestations }\end{array}$ & TSM & 2.5 & Frontotemporal & Total & & Stationary \\
\hline 20 & 56 & $\mathrm{~F}$ & $\begin{array}{c}\text { Visual } \\
\text { manifestations } \\
\text { Headache }\end{array}$ & PSM & 4.6 & $\begin{array}{l}\text { Bilateral } \\
\text { subfrontal }\end{array}$ & Subtotal & CSF leak & Stationary \\
\hline 21 & 49 & $F$ & $\begin{array}{c}\text { Visual } \\
\text { manifestations } \\
\text { Headache }\end{array}$ & PSM & 4 & $\begin{array}{c}\text { Bilateral } \\
\text { subfrontal }\end{array}$ & Total & & Stationary \\
\hline 22 & 56 & $\mathrm{~F}$ & $\begin{array}{c}\text { Visual } \\
\text { manifestations } \\
\text { Headache }\end{array}$ & PSM & 4 & $\begin{array}{l}\text { Unilateral } \\
\text { subfrontal }\end{array}$ & Total & & Stationary \\
\hline 23 & 54 & $F$ & Seizure & PSM & 2.2 & $\begin{array}{l}\text { Unilateral } \\
\text { subfrontal }\end{array}$ & Total & $\begin{array}{l}\text { Diabetes } \\
\text { insipidus }\end{array}$ & \\
\hline 24 & 52 & $\mathrm{~F}$ & $\begin{array}{c}\text { Visual } \\
\text { manifestations }\end{array}$ & PSM & 2.4 & $\begin{array}{l}\text { Unilateral } \\
\text { subfrontal }\end{array}$ & Total & & Stationary \\
\hline 25 & 48 & M & $\begin{array}{c}\text { Headache } \\
\text { Visual } \\
\text { manifestations }\end{array}$ & OGM & 6.9 & $\begin{array}{l}\text { Bilateral } \\
\text { subfrontal }\end{array}$ & Subtotal & Mortality & $\begin{array}{l}\text { Couldn't be } \\
\text { assessed }\end{array}$ \\
\hline 26 & 39 & M & $\begin{array}{l}\text { Anosmia } \\
\text { Headache } \\
\text { Behavioral } \\
\text { changes }\end{array}$ & OGM & 6.7 & $\begin{array}{l}\text { Bilateral } \\
\text { subfrontal }\end{array}$ & Total & Seizure & \\
\hline 27 & 47 & M & $\begin{array}{c}\text { Headache } \\
\text { Behavioral } \\
\text { changes }\end{array}$ & OGM & 6 & $\begin{array}{l}\text { Unilateral } \\
\text { subfrontal }\end{array}$ & Total & CSF leak & \\
\hline 28 & 61 & M & $\begin{array}{c}\text { Visual } \\
\text { manifestations }\end{array}$ & TSM & 4 & $\begin{array}{c}\text { Basal } \\
\text { interhemispheric }\end{array}$ & Total & $\begin{array}{l}\text { Diabetes } \\
\text { insipidus }\end{array}$ & Stationary \\
\hline 29 & 58 & M & $\begin{array}{c}\text { Visual } \\
\text { manifestations } \\
\text { Headache }\end{array}$ & PSM & 4 & $\begin{array}{l}\text { Bilateral } \\
\text { subfrontal }\end{array}$ & Total & & Stationary \\
\hline 30 & 54 & M & $\begin{array}{l}\text { Headache } \\
\text { Seizure }\end{array}$ & PSM & 2.6 & $\begin{array}{l}\text { Bilateral } \\
\text { subfrontal }\end{array}$ & Total & & \\
\hline
\end{tabular}

Table II: Size of Different Tumor Types

\begin{tabular}{|l|c|}
\hline Location & Mean diameter \\
\hline Olfactory groove & $5.8 \pm 1.9 \mathrm{~cm}$ \\
\hline Planum sphenoidale & $3.4 \pm 1.2 \mathrm{~cm}$ \\
\hline Tuberculum sellae & $2.5 . \pm 1.1 \mathrm{~cm}$ \\
\hline
\end{tabular}

The most common pathologic type found in our study was the Meningothelial type (50\%), followed by the Transitional type (23\%); Psammomatous type (17\%), Fibrous type (6.7\%). Atypical meningioma (WHO grade II) was present in only one patient (3.3\%).

Tumor excision: Total removal (Simpson grades I \&II) was achieved in 26 patients (86.7\%). Subtotal excision (Simpson grades III \&IV) was achieved in 4 cases (13.3\%). The highest percentage of total excision was in TSM cases, followed by PSMs, and then OGMs (Table IV). Tumors less than $4 \mathrm{~cm}$ in
Table III: Surgical Approaches Used in the Study

\begin{tabular}{|l|c|}
\hline Surgical approach & Patient no. \\
\hline Unilateral subfrontal & 12 cases $(40 \%)$ \\
\hline Bilateral subfrontal & 12 cases $(40 \%)$ \\
\hline Frontotemporal & 5 cases $(16.6)$ \\
\hline Basal interhemispheric & 1 case $(3.3)$ \\
\hline
\end{tabular}

size were associated with a higher incidence of total removal (Table V).

Clinical outcome: Among the 19 cases complaining of visual deterioration, the visual outcome could not be assessed in 2 cases postoperatively due to deterioration in the conscious level. 7 of the remaining 17 cases $(41.2 \%)$ showed improvement, while the remaining 10 cases $(58.8 \%)$ showed no postoperative change. Concerning postoperative complications, CSF leakage was the most seen complication followed by brain edema (Table VI). 
Table IV: Meningioma Location and Degree of Surgical Resection

\begin{tabular}{|l|c|c|c|}
\hline \multirow{2}{*}{ Completeness of excisions } & Total removal & Subtotal removal & Total \\
\cline { 2 - 4 } Olfactory groove & Grade I \& II & $3(21.5 \%)$ & 14 \\
\hline Planum sphenoidale & $11(78.5 \%)$ & $1(14.3)$ & 7 \\
\hline Tuberculum sellae & $6(85.7)$ & 0 & 9 \\
\hline Total & $9(100 \%)$ & $4(13.3 \%)$ & 30 \\
\hline
\end{tabular}

Table V: Relation Between Tumor Size and Degree of Surgical Excision

\begin{tabular}{|l|c|c|c|}
\multirow{2}{*}{ Meningioma size } & Total removal & Subtotal removal & Total \\
\cline { 2 - 4 } & Grade I \& II & Grade III \& IV & 2 \\
\hline Less than $2 \mathrm{~cm}$ & $2(100 \%)$ & 0 & 9 \\
\hline $4 \mathrm{~cm}-3.9 \mathrm{~cm}$. & $9(100 \%)$ & 0 & 14 \\
$6 \mathrm{~cm}-7.9 \mathrm{~cm}$. & $12(85.7 \%)$ & $2(14.3 \%)$ & 5 \\
\hline Total & $3(60 \%)$ & $2(40 \%)$ & 30 \\
\end{tabular}

We had two mortalities in our study (6.7\%); one was caused by postoperative anterior cerebral artery infarction, and the other was due to massive brain edema, for which bifrontal decompressive surgery was done and postoperatively she had bifrontal venous infarction.

General outcome: The median preoperative Karnofsky scale was 85 ranging from 70 to 100 . The median postoperative Karnofsky scale was 90 ranging from 0 to 100.

Follow-up and recurrences: The average duration for followup in our study was 14 months, ranging from 8 to 18 months. Given the fact that this was a short period for follow up, we did not meet any tumor recurrences.

\section{DISCUSSION}

Direct surgical excision remains the only treatment for midline anterior skull base meningiomas, total surgical excision with minimal postoperative morbidities remain a challenge for all neurosurgeons. Variability of surgical approaches as well as improved microsurgical skills made this challenge achievable in most cases. Different surgical approaches were utilized in this study as a trial to identify the optimal surgical route to target these lesions.

The mean age of the cases in our study was 51.5 years and $73.3 \%$ of the cases were in their $5^{\text {th }}$ and $6^{\text {th }}$ decades. $80 \%$ of our cases were females. These facts were matching with many of previous studies and literature review $(1,11,16)$. We found that headache was the most presenting symptom followed by visual manifestations, then anosmia and behavioral changes. These clinical manifestations were the main symptoms discussed in most studies concerned with our subject, but alternating in order. Zivgaridis et al. had visual manifestations first in order (17), while in the study by Turazzi et al. behavioral changes came first in order (15). The classic FosterKennedy syndrome was not a common presentation in our
Table VI: Postoperative Complications

\begin{tabular}{|l|c|}
\hline Complications & Patients no. \\
\hline CSF rhinorrhea & $6(20 \%)$ \\
\hline Brain swelling & $4(13.3)$ \\
\hline diabetes insipidus & $3(10 \%)$ \\
Seizure & $3(10 \%)$ \\
\hline Wound Infection & $1(3.3 \%)$ \\
Hydrocephalus & $1(3.3 \%)$ \\
\hline
\end{tabular}

study; it was only met in $6.7 \%$ of cases. Midline anterior skull base meningiomas, especially OGMs have to reach large sizes before they clinically present. More posterior lesions can present at smaller sizes due to their proximity to the optic nerves and the chiasm. In our study, the average size of the TSMs was $2.5 \mathrm{~cm}$, PSMs was $3.4 \mathrm{~cm}$, while the average size of the OGMs was $5.8 \mathrm{~cm}$. In the study by Turazzi et al., $60 \%$ of the cases had tumors larger than $6 \mathrm{~cm}$ (15).

Various surgical approaches were described in excising anterior skull meningiomas; every approach has its advantages as well as its limitations. Selection of a surgical approach depends on the tumor size, location, extension, in addition to the surgeon's experience in using that approach. In this study, we used the bifrontal approach in cases with large symmetrical midline lesions (8 large OGMs which had diameters more than $5 \mathrm{~cm}$ and 4 cases of PSMs) due to the excellent view for dissection of the both anterior cerebral arteries and the optic pathways. We used the unilateral subfrontal approach in 12 cases (4 OGMs, 5 TSMs, and 3 cases of PSMs), while Pterional approach was used in 5 cases (2 OGMs, and 3 TSMs). Bifrontal basal interhemispheric approach was used in one case (TSM). No statistical significance was found in the rate of total tumor resection (Simpson Grade 1 or 2) between the three main approaches. Total tumor removal was achieved in 26 cases 
Table VII: Major Series of OGMs that Reported Postoperative Recurrence Rates

\begin{tabular}{|l|c|c|c|c|}
\hline Series & $\begin{array}{c}\text { Total number of } \\
\text { cases }\end{array}$ & $\begin{array}{c}\text { Mean follow-up all } \\
\text { cases (months) }\end{array}$ & $\begin{array}{c}\text { Number of } \\
\text { recurrences } \\
\text { (age/sex) }\end{array}$ & $\begin{array}{c}\text { Time to recurrence } \\
\text { (months) }\end{array}$ \\
\hline Romani et al. 2009 (12) & 66 & 67 & 4 & 29 \\
\hline Bassiouni et al. 2007 (1) & 56 & 45 & 5 & 51 \\
\hline Nakamura et al. 2007 (10) & 82 & 63 & 4 & 55 \\
\hline Spektor et al. 2005 (14) & 80 & 71 & 0 & N/A \\
\hline Obeid and Al-Mefty, 2003 (11) & 15 & NA & 6 & 76 \\
\hline
\end{tabular}

(86.7\%). El Gindi also described various approaches for surgical treatment of olfactory groove meningiomas. He preferred the bifrontal approach for large, midline lesions (5). Obeid and AlMefty preferred the unilateral subfrontal approach for OGMs while others stressed the disadvantages associated with the subfrontal approaches and advocated the pterional approach for the removal of olfactory groove meningiomas as it allows direct visualization of the vessels that are to be dissected from the posterior surface of the lesions $(3,11)$.

Postoperative morbidities are still accepted when dealing with large midline skull base lesions but they are less frequently met with modern surgical techniques and good choice of the surgical approach. In our study, the highest complication rate was $20 \%$ for CSF leakage, there were only 2 mortalities (6.7\%). These results agree with other recently published studies $(9,11)$. In our study, none of our cases had tumor recurrences during the follow up period which extended up to 18 months. A longer follow up period is requested for better assessment of the actual recurrence rate. Several series have been published on these tumors, with long term follow up for recurrences beyond 10 years following Simpson 1 or 2 grade resections and they are illustrated in Table VII (8).

\section{CONCLUSION}

OGMs, TSMs, and PSMs are common midline anterior skull base lesions; they are more common in females, with the peak incidence in the sixth decade of life. These tumors are no longer an unsolvable problem. Different surgical approaches are available for treating these lesions; the commonest are the subfrontal approach followed by the pterional approach. Surgical management using all available technical tools has become effective and safe in aggressive tumor excision with minimal surgical morbidities and mortalities.

\section{REFERENCES}

1. Bassiouni H, Asgari $\mathrm{S}$, Stolke D: Tuberculum sellae meningiomas: Functional outcome in a consecutive series treated microsurgically. Surg Neurol 66: 37-45, 2006

2. Benjamin V, Russell $\mathrm{S}$ : The microsurgical nuances of resecting tuberculum sellae meningiomas. Neurosurgery 56 ONS Suppl 2:411-417, 2005

3. D'Avella D, Salpietro FM, Alafaci C, Tomasello F: Giant olfactory meningiomas: The pterional approach and its relevance for minimizing surgical morbidity. Skull Base Surg 9(1):23-31, 1999
4. De MonteF:Surgical treatment of anterior basal meningiomas. J Neuro-Oncol 29:239-248, 1996

5. El Gindi S: Olfactory groove meningioma: Surgical techniques and pitfalls. Surg Neurol 54:415-417, 2000

6. Goel A, Muzumdar D: Surgical strategy for tuberculum sellae meningiomas. Neurosurg Q 15: 25-32, 2005

7. Karnofsky DA, Burchenal JH: The clinical evaluation of chemotherapeutic agents in cancer. In: MacLeod CM (ed), Evaluation of Chemotherapeutic Agents. New York: Columbia Univ Press, 1949:196

8. Lyons MK, Birch DB: Long-Term follow-up and clinicohistopathological features of Simpson grade 1 surgical resection of large olfactory groove meningioma. Open Neurosurgery J 4:18-23, 2011

9. Mathiesen T, Kihlstrom L: Visual outcome of tuberculum sellae meningiomas after extradural optic nerve decompression. Neurosurgery 59:570-576, 2006

10. Nakamura M, Struck M, Roser F, et al: Olfactory groove meningiomas: clinical outcome and recurrence rates. Neurosurgery 60:844-852, 2007

11. Obeid F, Al-Mefty O: Recurrence of olfactory groove meningiomas. Neurosurgery 53: 534-543, 2003

12. Romani $R$, Lehecka $M$, Gaal $E$, et al: Lateral supraorbital approach applied to olfactory groove meningiomas: experience with 66 consecutive patients. Neurosurgery 65(1): 39-53, 2009

13. Simpson D: The recurrence of intracranial meningiomas after surgical treatment. J Neurol Neurosurg Psychiatry 20:22-39, 1957

14. Spektor S, Valarezo J, Fliss D, et al: Olfactory groove meningiomas from neurosurgical and ear, nose and throat perspectives: approaches, techniques and outcomes. Operative Neurosurgery 57: 268-280, 2005

15. Turazzi S, Cristofori L, Gambin R: The pterional approach for the microsurgical removal of olfactory groove meningiomas. Neurosurgery 45:821-826, 1999

16. Whittle IR, Smith C, Navoo P, Collie D: Meningiomas. Lancet 365:1535-1543, 2004

17. Zivgaridis D, Medele RJ, Muller A, Hischa AC: Meningiomas of the sellar region presenting with visual impairment: Impact of various prognostic factors on surgical outcome in 62 patients. Acta Neurochir (Wien) 143: 471-476, 2001 